\title{
SOSIALISASI DAN PENDAMPINGAN PERLINDUNGAN ANAK TERPADU BERBASIS MASYARAKAT (PATBM) SEBAGAI UPAYA MEWUJUDKAN DESA LAYAK ANAK DI DESA PANARAGAN JAYA UTAMA, KAB. TULANG BAWANG BARAT
}

\author{
Emilia Susanti ${ }^{1 *} \&$ Dona Raisa Monica ${ }^{2}$ \\ 1,2 Bagian Pidana, Fakultas Hukum, Universitas Lampung \\ Jl. Prof. Dr. Ir. Sumantri Brodjonegoro No.1, Gedongmeneng, Rajabasa, Kota Bandar Lampung, \\ Indonesia \\ *Korespondensi: emilia.susanti@fh.unila.ac.id
}

\begin{abstract}
Abstrak
Salah satu segmen masyarakat yang sangat strategis untuk ditingkatkan pengetahuan, sikap dan perilakunya adalah isu perlindungan anak. Kebijakan strategis pemerintah terkait perlindungan anak adalah dengan melibatkan seluruh lapisan masyarakat melalui konsep Perlindungan Anak Terpadu Berbasis Masyarakat (PATBM). Melalui PATBM, masyarakat diharapkan mampu mengenali, menelaah, dan mengambil iisiatif untuk mencegah dan memecahkan permasalahan kekerasan terhadap anak yang ada di lingkungan sendiri yang pada akhirnya akan mendukung program Desa Layak Anak. Kegiatan sosialisasi dan pendampingan perlindungan anak terpadu berbasis masyarakat di Desa Panaragan Jaya Utama, Kecamatan Tulang Bawang Tengah Kabupaten Tulang Bawang Barat ini bertujuan untuk meningkatkan pengetahuan, sikap, perilaku dan partisipasi masyarakat dalam perlindungan anak. Kegiatan ini melipatkan aparatur desa Panaragan Jaya Utama, Lembaga Perlindungan Anak (LPA) Kabupaten Tulang Bawang Barat dan Kepolisian Sektor (POLSEK) Tulang Bawang Tengah sebagai mitra dan pemateri kegiatan. Kegiatan ini dilakukan dengan metode ceramah, tanya jawab, diskusi terfokus dan bimbingan klinis.
\end{abstract}

Kata kunci: sosialisasi, pendampingan, PATB

\section{ANALISIS SITUASI}

Menurut ketentuan Pasal 1 UU No. 35 Tahun 2014 yang di maksud dengan anak adalah seseorang yang belum berumur 18 (delapan belas) tahun termasuk anak yang masih dalam kandungan. Selanjutnya menurut Pasal 1 Angka 16 UU No. 35 Tahun 2014 menyebutkan bahwa Kekerasan adalah setiap perbuatan terhadap Anak yang berakibat timbulnya kesengsaraan atau penderitaan secara fisik, psikis, seksual, 
dan/atau penelantaran, termasuk ancaman untuk melakukan perbuatan, pemaksaan, atau perampasan kemerdekaan secara melawan hukum.

Kegiatan PATBM pada dasarnya merupakan kegiatan yang dilaksanakan di tingkat desa atau kelurahan. Ruang lingkup kegiatan PATBM mencakup upaya-upaya untuk mencegah kekerasan terhadap anak dan merespon atau menanggapi jika terjadi kekerasan terhadap anak melalui pengembangan jejaring dengan penyedia pelayanan pendukung yang terjangkau berkualitas seperti Pusat Pelayanan Terpadu Perlindungan Perempuan dan Anak (P2TP2A), Lembaga Kesejahtraan Sosial (LKS), atau Lembaga Swadaya Masyarakat (LSM) yang bergerak dalam perlindungan anak atau penanganan kekerasan, pusat kesehatan masyarakat (Puskesmas), kepolisian sektor (Polsek), Lembaga Bantuan Hukum (LBH), bintara Pembina Desa (Babinsa) dan institusi sosial yang ada di masyarakat. Adapun tujuan dari program PATBM sesuai dengan pengembangan indikator Kota/Kabupaten Layak Anak adalah untuk mencegah kekerasan terhadap anak dan menanggapi kekerasan pada anak di Indonesia.

Mardiyanti (2015) menegaskan bahwa masyarakat perlu terlibat dalam upaya perlindungan anak. Keberadaan PATBM merupakan langkah strategis dalam perlindungan terhadap anak oleh sebab itu perlu sinergitas oleh semua pemangku kepentingan untuk pengembangan PATBM mulai dari lapisan masyarakat paling bawah yaitu desa. Oleh sebab itu perlu dilakukan upaya meningkatkan pengetahuan dan kesadaran masyarakat dalam melakukan perlindungan anak terpadu berbasis masyarakat. Namun dalam pengembangan dan peningkatan PATBM masih terkait dengan beberapa kendala diantaranya fenomena jumlah kekerasan terhadap anak yang cukup signifikan dan makin beragam permasalahnnya, masih banyak daerah kabupaten/kota dan desa/kelurahan yang belum terjangkau untuk menjadi model PATBM serta minimnya pemangku kebijakan/fasilitator/aktivis/pemerhati anak yang terlatih PATBM. Selain itu hambatan pengembangan PATBM adalah kurangnya dukungan para tokoh masyarakat, agama, dan lembaga adat, serta faktor kultur, budaya dan agama yang berbeda-beda di Indonesia.

Berdasarkan pra-survey pada Lembaga Perlindungan Anak Kab.Tulang Bawang Barat (LPA Tubaba) Ketua lembaga LPA Tulang Bawang Barat Elia Sunarto menjelaskan bahwa, kasus kekerasan anak di Tulang Bawang Barat cenderung semakin meningkat. LPA mencatat sepanjang Tahun 2018 terjadi peningkatan kasus pelanggaran hak anak. Data tersebut berasal dari pengaduan masyarakat dan keluarga korban pelanggaran hak anak denga total mencapai 48 kasus yang didominasi oleh kasus perlakuan salah dan penelantaran anak sebanyak 16 (enam belas) kasus, diikuti oleh 12 (dua belas) kasus kekerasan fisik dan psikis, serta 9 (sembilan) kasus kekerasan seksual. Hal ini 
mengindikasikan bahwa banyak nya kekerasan terhadap anak khususnya di kecamatan Tulang Bawang Barat.

Tabel 1. Data Kekerasan Anak di Kab. Tulang Bawang Barat Tahun 2018

\begin{tabular}{clc}
\hline No & \multicolumn{1}{c}{ Jenis Kasus } & Jumlah \\
\hline 1 & Penelantaran Anak & 16 Kasus \\
2 & Kekerasan Fisik dan Psikis & 12 Kasus \\
3 & Kekerasan Seksual & 9 Kasus \\
\hline & Jumlah & 37 Kasus
\end{tabular}

Sumber: Dokumen LPA Kab. Tulang Bawang Barat, 2018.

Hal ini mengindikasikan bahwa banyaknya kekerasan terhadap anak khususnya di kecamatan Tulang Bawang Barat. Ketua LPA Tulang Bawang Barat menyatakan bahwa salah satu faktor penyebab tingginya angka kekekrasan terhadap anak di wilayah Kab. Tulang Bawang Barat adalah kurangnya peran serta masyarakat dalam memberikan perlindungan terhadap anak khususnya melalui program Perlindungan Ana Terpadu Berbasis Masyarakat (PATBM). Oleh sebab itu perlu dilakukan edukasi dan pembentukan lembaga PATBM khususnya pada desa yang memiliki resiko tinggi terhadap kasus kekerasan terhadap anak. Selain itu perlu dilakukan sosialisasi dan penyuluhan hukum sebagai upaya dalam meningkatkan pengetahuan, pemahaman dan kesadaran masyarakat mengenai kekerasan dan perlindungan pada anak, seperti yang ditegaskan oleh Sulistiowati dkk (2020). Hal ini perlu dilakukan mengingat sebagian besar faktor penyebab terjadinya kekerasan terhadap anak di Tulang Bawang Barat adalah berkaitan dengan budaya dan perlakuan yang salah. Adapun lokasi yang dianggap paling urgen untuk dilakukan kegiatan pengabdian ini adalah pada Desa Panaragan Jaya Utama Kecamatan Tulang Bawang Tengah.

Desa Panaragan Jaya Utama terletak di Kecamatan Tulang Bawang Tengah Kabupaten Tulang Bawang Barat. Desa Panaragan Jaya Utama dapat ditempuh selama kurang lebih empat jam dari kota Bandar Lampung dan merupakan daerah semi perkotaan yang difasilitasi dengan kondisi jalan yang cukup baik dan perekonomian masyarakat yang didukung oleh sektor perkebunan dan pertanian. Berdasarkan hasil pra survey menurut Kepala Desa Panaragan Jaya Utama tingkat kesadaran masyarakat dalam perlindungan anak masih rendah, belum dibentuknya Satuan Tugas (Satgas) Prlindungan Anak Terpadu Berbasis Masyarakat (PATBM). Selain itu potensi resiko kekerasan terhadap anak di Desa Panaragan Jaya Utama sangat tinggi baik anak sebagai pelaku maupun anak sebagai korban.

Pola kerja PATBM ini sangat partisipastif dengan melibatkan semua unsur dari masyarakat yang berkepentingan dengan perlindungan anak untuk menjamin terpenuhinya hak-hak anak terbebas dari perlakukan kekerasan di masyarakat. Peran organisasi kemasyarakatan dan lembaga pendidikan, yang dilakukan dengan cara 
mengambil langkah yang diperlukan sesuai tugas, fungsi, dan kewenangan masingmasing untuk membantu penyelenggaraan perlindungan anak.

Titik berat kegiatan PATBM adalah kegiatan promotif dan pencegahan untuk menghindari terjadinya kekerasan. Upaya untuk promosi dan pencegahan ini dilakukan dengan tujuan untuk membangun norma anti kekerasan, meningkatkan kemampuan orang tua untuk mengasuh anak yang jauh dari nilai kekerasan dan meningkatkan kemampuan anak untuk bisa melindungi diri dari kemungkinan terjadinya tindak kekerasan pada dirinya. Kegiatan menolong korban tidak sepenuhnya ditangani melalui PATBM.

PATBM membantu agar korban dapat cepat dideteksi dan ditolong, korban dengan cepat dan mudah mencari pertolongan. PATBM mendampingi atau mempermudah korban dan keluarga mendapat pertolongan dengan merujuk pada lemabaga-lembaga pelayanan yang sesuai dengan permasalahan dan kebutuhan mereka. Kegiatan PATBM ini merupakan kegiatan yang terpadu sehingga mengarah pada kegiatan yang bersifat kontinum dan sistemik, mencakup pengenalan terhadap terjadinya kekerasan, penyebab, risiko, dan faktor-faktor yang menguatkan perlindungan anak yang ada, mengembangkan rencana kegiatan pencegahan yang ditujukan untuk menghilangkan atau mengurangi faktor-faktor penyebab dan menguatkan faktor perlidungan, baik pada anak, orang tua, keluarga, dan masyarakat.

Efektivitas pelaksanaan PATBM antara lain ditentukan oleh pengorganisasian yang mengatur secara jelas tugas-tugas atau mandat para pihak serta dukungan regulasi yang memberi kekuatan hukum bagi penyelenggaraan kegiatan. Sinergitas regulasi dan tata kelola organisasi di tingkat pusat, provinsi, kabupaten hingga ke tingkat desa/kelurahan di mana PATBM dilaksanakan harus dibangun dengan baik. Oleh karena itu, untuk mewujudkan PATBM perlu diupayakan pengembangan atau optimalisasi regulasi dan pengembangan tata kelola organisasi di berbagai tingkatan tersebut.

Berdasarkan latar belakang tersebut, artikel ini akan mendeskripsikan implementasi dari Undang-Undang No 35 Tahun 2014 Tentang Perlindungan Anak dan UndangUndang Nomor 11 Tahun 2012 Tentang Sistem Peradilan Anak dalam penyelenggaraan perlindungan anak dan desa layak anak di Desa Panaragan Jaya Utama Kabupaten Tulang Bawang Barat.

\section{METODE PELAKSANAAN}

Dalam pelaksanaan sosialisasi menggunakan metode ceramah dan diskusi. Metode ceramah dan diskusi serta FGD (Focus Group Discussion) di dalam ruangan yang digunakan untuk menyajikan materi. Dalam teknis pelaksanaannya dapat dijelaskan sebagai berikut : 
1. Tim menyampaikan materi melalui ceramah dengan menggunakan LCD dan hard copy power point sebagai media utama. Materi yang akan disampaikan terkait pentingnya keterlibatan seluruh lapisan masyarakat dalam perlindungan anaak dan pentingnya peran pemerintah desa dalam menyelenggarakan PATBM dalam rangka terwujudnya Desa Layak Anak.

2. Diskusi dan Tanya jawab antara peserta dan pemateri terkait tugas, fungsi dan peran strategis masyarakat dalam penyelenggaraan perlindungan anak berbasis masyarakat (PATBM) dan bagaimana membentuk satuan tugas PATBM.

3. Pelayanan Klinis, melalui metode ini masyarakat diberikan pengetahuan bagaimana menyelenggarakan perlindungan anak terpadu berbasis masyarakat dan bagaimana harus bertindak apabila terdapat kasus kekerasan terhadap anak dilingkungannya (Kemen PPA, 2015). Selain itu masyarakat juga diberikan pengetahuan bagaimana penanganan hukum terhadap kasus kekerasan anak, baik pada kasus anak pelaku maupun anak sebagai korban.

4. Kegiatan pendampingan dilakukan melaluikonseling terkait penyelenggaraan dan pembentukan satuan tugas perlindungan anak terpadu berbasis masyarakat (PATBM) di Desa Panaragan Jaya Utama, Kecamatan Tulang Bawang Tengah, Kabupaten Tulang Bawang Barat.

\section{PELAKSANAAN DAN HASIL}

Kabupaten Tulang Bawang Barat adalah salah satu kabupaten di Provinsi Lampung, Indonesia. Kabupaten ini diresmikan oleh Menteri Dalam Negeri Indonesia, Mardiyanto, pada 29 Oktober 2008, sebagai pecahan dari Kabupaten Tulang Bawang. Luas Kabupaten Tulang Bawang Barat $1.201 \mathrm{Km}^{2}$. Sosialisasi dan Pendampingan Perlindungan Anak Terpadu Berbasis Masyarakat (PATBM) Sebagai Upaya Mewujudkan Desa Layak Anak Di Desa Panaragan Jaya Utama, Kab. Tulang Bawang Barat ditanggapi secara positif dan antusias oleh tokoh-tokoh adat, masyarakat dan aparatur desa yang menjadi peserta pengabdian. Hal ini terbukti dengan banyaknya pertanyaan dan berkembangnya diskusi seusai tim pengabdian menyampaikan presentasi. Disamping itu, keseriusan para peserta dalam mengikuti presentasi, membuat peserta tidak beranjak dan tetap mengikuti kegiatan sampai dengan selesai. 


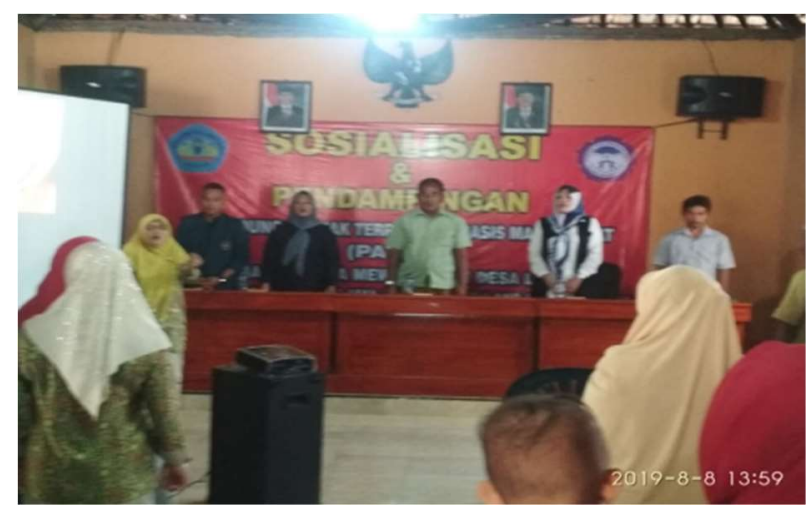

Gambar 1. Kegiatan Sosialisasi dan Pendampingan PATBM Sumber: Hasil Pengabdian, 2020.

Secara kuantitatif nilai rata-rata peserta sebelum dilaksanakan kegiatan adalah 68,62 dan mengalami kenaikan menjadi 89,61 setelah dilaksanakan kegiatan pelatihan. Kenaikan rata-rata sebesar 3,94 poin. Baik nilai pre test maupun post test tertinggi adalah 89 dan nilai terendah 67. Nilai dasar yang cukup tinggi ini secara tidak langsung menggambarkan pengetahuan dan pemahaman masyarakat Desa Panaragan Jaya Utama secara keseluruhan sudah sangat baik.

Berdasarkan hasil tersebut di atas maka dapat disimpulkan bahwa kegiatan pengabdian ini mampu memberikan dampak positif secara kognitif terhadap pengetahuan tentang kekerasan dan hak-hak anak. Sedangkan dari sisi afektif peserta menghasilkan komitmen untuk mendukung upaya Desa Panaragan Jaya Utama menjadi Desa Layak Anak. Hasil sosialisasi dan penyuluhan juga ditindak lanjuti oleh kepala desa dan perngkatnya dalam pembentukan dan pengaktivan komunitas PATBM di desa Desa Panaragan Jaya Utama.

\section{PENUTUP}

Kegiatan ini menyimpulkan perlu adanya pelatihan berkelanjutan tentang Sosialisasi dan Pendampingan Perlindungan Anak Terpadu Berbasis Masyarakat (PATMB) sebagai upaya mewujudkan Desa Layak Anak sehingga masyarakat lebih memahami dan dapat mengaplikasikan ilmu yang didapat secara langsung.

\section{UCAPAN TERIMA KASIH}

Terimakasih kepada LPPM Universitas Lampung atas pendanaan kegiatan pengabdian melalui Hibah BLU DIPA UNILA Pengabdian Skema Pemula tahun 2019 dan terimakasih serta penghargaan yang setinggi-tingginya kepada masyarakat Desa Panaragan Jaya Utama Kecamatan Tulang Bawang Tengah Kabupaten Tulang Bawang Barat. 


\section{DAFTAR PUSTAKA}

Mardiyati, A. (Desember, 2015). Peran Keluarga dan Masyarakat dalam Perlindungan Anak Mengurangi Tindak Kekerasan. Jurnal PKS, 14 (4): 453 - 464.

Kementerian Pemberdayaan Perempuan dan Perlindungan Anak. (2015). Pedoman Perlindungan Anak Terpadu Berbasis Masyarakat (PATBM) Edisi 1. Jakarta: Kemen PPA.

Sulistiowati, R., Prihantika, I., Khoiriah, S. \& Rudy. (2020). Peningkatan Kapasitas Advokasi Sosial dan Pendampingan Hukum pada Anggota Satuan Tugas Perlindungan Anak Terpadu Berbasis Masyarakat (Satgas PATBM) Garuda Hitam Pekon Mataram, Kabupaten Pringsewu. Sumbangsih, 1(1): 135-140.

Undang-Undang No 35 Tahun 2014 Tentang Perlindungan Anak.

Undang-Undang Nomor 11 Tahun 2012 Tentang Sistem Peradilan Pidana Anak. 
